\title{
COVID-19 OUTBREAK: AN ANALYSIS OF MALAYSIAN \\ household Income Class DuRing Movement Control Orders (MCO)
}

Mohd Khairi Ismail*

Faculty of Business \& Management

Universiti Teknologi MARA (UiTM)

Malaysia

khairiismail@uitm.edu.my

\section{Vikniswari Vija Kumaran}

Faculty of Business and Finance

Universiti Tunku Abdul Rahman (UTAR)

Malaysia

vikniswarivk@utar.edu.my

Siti Nurul Munawwarah

Department of Business \& Management Law

Management \& Science University

Malaysia

sitinurul_munawwarah@msu.edu.my

*Corresponding Author email: khairiismail@uitm.edu.my

Submission: 20 November 2020 Revised: 24 December 2020

Accepted: 19 January 2021

Peer-review under responsibility of 6th Asia International Conference 2020 (Online) Scientific Committee http://connectingasia.org/scientific-committee/

(C) 2021 Published by Readers Insight Publisher,

Office \# 6, First Floor, A \& K Plaza, Near D Watson, F-10 Markaz, Islamabad. Pakistan,

editor@readersinsight.net

This is an open access article under the CC BY license (http://creativecommons.org/licenses/4.0/). 


\section{A B S T R A C T}

The outbreak of COVID-19 has caused the Malaysian Government to take steps to implement the Movement Control Order (MCO) from 18th March 2020. According to Bank Negara Malaysia, the implementation of $\mathrm{MCO}$ affects the national income with the estimated economic growth of Malaysia in 2020 which is expected to be around $-2 \%$ to $0.5 \%$. The effect of MCO due to COVID-19 not only affects the macro level but at micro level as well, especially those group of household. The group of household who expected to face high economic risk and directly affect their consumption patterns during the implementation of MCO. This study will analyze the pattern of households' consumption in Malaysia based on different income groups which is $\mathrm{B} 40$ and $\mathrm{M} 40$ during the implementation of MCO due to the spread of COVID-19 pandemic. The findings show that the household experienced change in daily consumption patterns after the implementation of MCO. In addition, due to insufficient savings causes the households to be very worried for their consumption if the MCO is further extended for 6 months.

Keywords: COVID-19; Movement Control Order (MCO); B4O \& M40 Household Consumption

\section{R E S E A R H H I G H L I G H T}

The household experienced change in daily consumption patterns after the implementation of MCO.

Due to insufficient savings causes the households to be very worried for their consumption if the $\mathrm{MCO}$ is further extended for 6 months.

The study identified the types of spending components that affect the income of B40 people.

\section{G R A P I C A L A B S T R A C T}

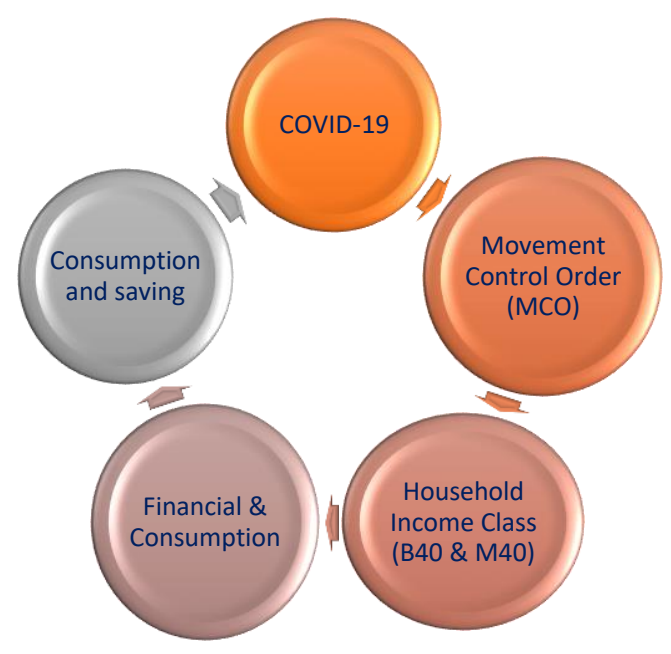

\section{Research Objectives}

The effect of MCO due to COVID-19 not only affects the macro level but at micro level as well, especially those group of household. The group of household who expected to face 
high economic risk and directly affect their consumption patterns during the implementation of MCO. This study will analyze the pattern of households' consumption in Malaysia based on different income groups which is $\mathrm{B} 4 \mathrm{O}$ and $\mathrm{M} 40$ during the implementation of MCO due to the spread of COVID-19 pandemic.

\section{Methodology}

This study is based quantitative research. Data were collected via online survey. Distribution of online survey was between 1 April 2020 to 30 May 2020 for the whole of Malaysia. Prior to the distribution of the survey, the population determination is necessary to ensure sampling can be done. For this study, population under B40 (Bottom 40\%) as those with household income of less than RM4,360 per month and M40 (Middle 40\%) with household income between RM4,360 and RM9,619 that have registered in the information system of the Department of Statistics Malaysia have been chosen. According to Krejcie \& Morgan (1970), if the total population exceeds 100,000 people, researchers need a total of 384 samples for analysis and it is sufficient to describe the characteristics of the population. In this study, M40 the population of B40 households in Malaysia is 2.78 million people and this means that this study needs at least 384 respondents. However, this study used 504 respondents from $\mathrm{B} 4 \mathrm{O}$ group and 257 respondents from M40 as the study sample. Study analysis used descriptive analysis and multiple regression analysis.

\section{Results}

Financial analysis involves the impact of the implementation of MCO in terms of financial and savings sources, availability of savings, financial capability to recover, planning to restore financial resources, and action taken in the event of emergencies such as MCO in the future. The majority of respondents stated that the implementation of MCO affects their financial and savings sources. Analysis of respondents' savings for spending shows that 45 percent of respondents have savings of less than 1 month of spending. In addition, a high percentage also indicates a situation where 38.5 percent of respondents have savings of 1 to 3 months only. Move to the analysis of the savings owned by the respondents shows that it is for the purchase of basic and main things, namely buying food supplies, paying utility bills, medicines, spending petrol. For spending on things like investing and entertainment spending shows a low percentage. Respondents also provided feedback on the issue of their financial ability to recover after the contents of COVID-19 and the implementation of MCO. The majority of respondents stated that their finances recovered within 1 to 6 months.

\section{Findings}

There are few actions taken by the government to overcome the effect of this pandemic especially to the economic. The government has provide Bantuan Prihatin Nasional (BPN) that focusing to the $\mathrm{B} 4 \mathrm{O}$ and $\mathrm{M} 4 \mathrm{O}$ groups to reduce the burden of these groups during this pandemic and to increase household cashflow as some of them are being retrenched from work and loss their business. Instead of BPN, government also come out with Moratorium 
where all housing loans and car loan can be deferred for six months. This is also part of government initiatives to lessen the burdens to those affected and allows the borrower to have better financial plan and provide some relief to those who struggling with a liquidity crisis. The lessons of the pandemic show how inequality-ridden governments struggle to function effectively 18. The government must have a robust and inclusive stimulus plan to support the poor, not only during the pandemic, but also after, in order to cushion the effects of the Covid-19 pandemic. Hopefully, Malaysia will be compelled by this pandemic to review its social policies. If the constructive steps put in place in response to this pandemic continue or bring about permanent changes in public health, social security and counter-cyclical measures, finance and reform, in particular to help marginalised disadvantaged groups, will ensure that this crisis is not wasted and that sustainable development and inequality are prevented from worsening.

\section{References}

Krejcie, R. V., \& Morgan, D. W. (1970). Determining sample size for research activities. Educational and psychological measurement, 30(3), 607-610.

\section{Author's Biography}

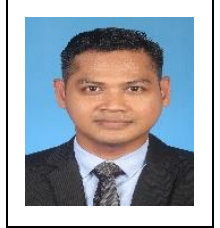

Mohd Khairi Ismail is a Senior Lecturer at Faculty of Business \& Management, Universiti Teknologi MARA (UiTM). He holds a Master of Economics and Doctor of Philosophy from Universiti Kebangsaan Malaysia (UKM), Malaysia. His research interests are in development economics, agricultural economics, environmental management and business management.

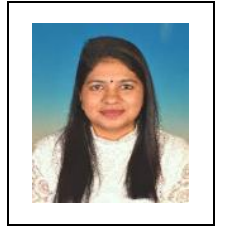

Vikniswari Vija Kumaran is an Assistant Professor in Department of Economics and Chairperson for Centre for Economic Studies (CES), Universiti Tunku Abdul Rahman (UTAR). She obtained her PhD degree in economic efficiency and productivity in 2016. Most of her publications were related to efficiency, renewable energy, and economic development. She has reviewed many internal research grants, journals, and conference papers.

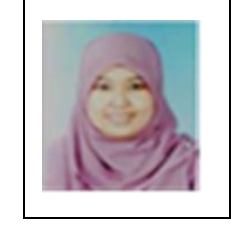

Siti Nurul Munawwarah Roslan is a lecturer at Management and Science University. She completed her first degree and Master in Economics from University of Malaya. Her research interest is in the field of urban neighbourhood and household studies. Siti Nurul Munawwarah Roslan is doing her PhD in Economics at University of Malaya in the field of Urban Economics. 